\title{
Regulatory Reform on Hydroelectric Power Plant Development in Indonesia
}

\author{
Naomi Helena Tambunan ${ }^{1}$ \\ Ministry of National Development Planning/BAPPENAS RI
}

\begin{abstract}
This research essay will examine whether or not regulatory reform will succeed in providing a good regulation that gives significant effect to the development agenda, particularly in developing of the hydroelectric power plant which eventually fulfil citizen's electricity needs. In order to obtain the license in developing hydroelectric power plant, the investor has to engage with at least 6 ministries at the national level and with the local government. The institutions are the Ministry of Public works, the Ministry of Energy and Mineral Resources, the Ministry of Forestry, Capital Investment Coordinating Board, State Electricity Company and Ministry of Finance. In each institution, the investors have to do some stages which mostly take a very long time. Until this recent time, the investors of hydroelectric power plant must comply with at least forty four national level regulations and should gain at least fourteen licenses from the various ministries. The figure does not include the license from the local government such as principle permits, location permits. Licenses zoning, building permits and nuisance permit (hinderordonnantie). Regulation problems that occurred in the process of developing hydroelectric power plant greatly hamper the effort on providing electricity to all Indonesia's citizen. To overcome this issue, national strategy on regulatory reform was made. While reconceptualization on regulatory making process strategy and the capacity building on the policy and regulatory maker strategy might increase the effectivity on the implementation of upcoming regulation, regulatory simplification is the effective strategy that can accurately overcome the existing regulatory problem in developing a hydroelectric power plant in Indonesia.
\end{abstract}

Keywords: regulatory reform, energy regulation 
Regulatory Reform on Hydroelectric Power Plant Development in Indonesia

\author{
Naomi Helena Tambunan, BAPPENAS
}

\title{
1. Introduction
}

In order to build its human life quality, Indonesian government needs to meet the energy needs of its people. Electricity is one of the people's basic needs. Currently, there are thousands of villages that have not been electrified. The hydroelectric power plant is a great potential for generating electricity to these villages. Unfortunately, there are some obstacles in building a hydroelectric power plant, such as the lengthy and convoluted licensing process. Licensing on developing hydroelectric power plant requires a lot of stages with many government institutions and it takes a very long period of time. This condition hampers the government's effort to fulfil people's basic needs.

For more than two decades, Indonesia's development planning document merely uses budget approach as the only delivery mechanism to implement development programs. In the latest medium term development planning document (20015-2019) ${ }^{2}$, the government initiated new delivery mechanism namely regulatory framework and institutional framework. The regulatory framework is crucial to develop because the previous development programs were planned and supported by adequate budget but mostly hampered by regulatory issues.

To thoroughly overcome this complicated conditions, Indonesia's government launched a national strategy on regulatory reform. There are four big strategies on this policy document such as simplification, deregulation, institutional restructuration, and improving the capacity of policy and regulatory maker. This national strategy is expected to overcome entire regulation problems.

If regulatory reform can improve the development of the hydroelectric power plant and give benefit to the wider community, more people might access the electricity and increase their productivity. This reform undoubtedly will also give the same good effect on the other development sector.

In order to implement this national strategy, some challenges might arise, such as its implementation in the local government (decentralization) and the use of an international indicator to measure the effectiveness of the strategy that can distract the focus of government agenda.

This research essay will examine whether or not regulatory reform will succeed in providing a good regulation that gives significant effect to the development agenda, particularly in developing of the hydroelectric power plant which eventually fulfil citizen's electricity needs.

\section{Literature Review: Regulation and its role in development}

Regulation has a variety meaning. According to Selznick, regulation is a control by the public agency that is focused and sustained over the activities that are socially valued. ${ }^{3}$ Kenneth Meier describes regulation as a government effort to control its citizens, corporations, and sub governments' behaviour. ${ }^{4}$

Regulation can also be distinguished in at least 5 terms..$^{5}$ The first term is Regulation as a systematic control, as an opposition to the market, as an instrument of policy, a form of law, and in opposition to the legislation. As a systematic control, regulation is define as an act which controls, direct and governs people's behaviour in accordance with a particular rule, principle or a system. Associated with its control function, regulation is commonly is defined as an instrument of the government to implement its policy and usually put in the form of law as formal sources for the state to command and control people's behaviour. Related to the discipline of economics, regulation is also defined as a control of the state to the market activities. The notion of regulation in most legal system is defined differently with laws. The law is defined as products of the democratically elected legislature while regulation is commonly known as legally binding

\footnotetext{
2. National Development Planning Agency, Indonesia Medium-Term Development Plan 2015-2019

3. P. Selznick, Focusing Organisational Research on Regulation (University of California Press, 1985) 363

4. Kenneth Meier, Regulation : Politics, Bureucracy, and Economics (St. Martin's Press, 1985).

5. International Association of Legal Science (ed), International Encyclopedia of Comparative Law (J.C.B. Mohr (Paul Siebeck), 1973) 3-4
} 
rules made by the government. Those myriad meaning and context of regulation refer to one important point that regulation is considered as a tool for restricting behaviour and preventing the emergence of an undesirable condition. ${ }^{6}$

The role of regulation in developing countries in regard to promoting economic growth and development shifted overtime. ${ }^{7}$ Around the 1960 s to 1980 s, regulation was made by the government to involve in overcoming market failure. In the early 1980s, the role of regulation was narrowed which used as an instrument to maintain and ensure market operation. It did not interfere significantly if the market was running well. ${ }^{8}$ The role of regulation is stronger when the market failure often occurs. ${ }^{9}$

The government in developing countries has to put a greater effort to achieve economic growth and sustainable development. ${ }^{10}$ Regulation is the main means that can be foster by governments in developing countries to promote activity and growth. ${ }^{11}$ Providing an efficient, reliable infrastructure that easily accessible to the community might be one of the best ways to increase the market development and the output growth. ${ }^{12}$

\subsection{Regulatory Approaches}

There are some approaches on scrutinizing how regulation emerges and develops, which can be divided into two factors such as exogenous and endogenous factors. ${ }^{13}$ Exogenous factors consist of three theories such as public interest theories, interest group theories, and the power of ideas, and the endogenous factors are the force by institutional cultures.

Public interest theory explains that regulation is made to pursuit public interest related objectives such as promoting general welfare to the community. ${ }^{14}$ While it seems impossible to make a regulation based on the public interest, there is a notion about interest group approach on developing a regulation which pursuit particularistic concerns of an interest group. This approach is closely associated with the notion of 'economic theory of regulation', where there is a role of private economic interest influencing the regulation. ${ }^{15}$ On the other hand, power of ideas approach comes from the idea, ideologies, or belief that emerges in some regime that influences the approach towards regulation. The idea, which bases on the assumed real social condition, are used to justify the policies of the leader. On this approach, it is sometimes hard to distinct whether or not the approach is based on the idea or from the role of economic interest. The endogenous factor is expresses the idea on the notion that institutional structure and arrangement are most likely shape the regulation. ${ }^{16}$

The notion public interest approach on regulatory-making was argued by public choices theorist because it is almost impossible to define and fulfil public interest. ${ }^{17}$ Regulators might fall into the condition and make the regulation in favour of particular interest. Beside the particular interest in the market or community, a greater threat on objective regulators might also come from political capture, influencing regulators to make a regulation to pursue their political ends. As an example, Regulation, apart from being used to manage its citizen behaviour, is also used as a means to managed and improve country's economic condition. The government, particularly in developing countries, sought to make their country most favourable to the investors to increase investment that will eventually lead to economic growth and social welfare. ${ }^{18}$ The policy on making this kind of regulation to attract investor as much as possible might eventually infringe the citizen's basic rights. ${ }^{19}$

\footnotetext{
6. Robert Baldwin, Martin Cave and Martin Lodge, Understanding Regulation: Theory, Strategy, and Practice (Oxford University Press, 2nd ed, 2012).

7. M Minogue, 'Apples and Oranges-Comparing International Experiences in Regulatory Reform' (2005) Occasional lecture 13 Centre for the Study of Regulated Industries, University of Bath.

8. Hossein Jalilian, Colin Kirkpatrick and David Parker. 'The Impact of Regulation on Economic Growth in Developing Countries: A Cross-Country Analysis' (2007) 35 World Development 87, 87

9. J Stiglitz, 'Private Uses of Public Interests: Incentives and Institutions' (1998) 12 Journal of Economic Perspectives 3.

10. Colin Kirkpatrick, David Parker and Yin-Fang Zhang, 'Foreign Direct Investment in Infrastructure in Developing Countries: Does Regulation

Make a Difference?' (2006) 15 Transnational Corporation 143.

11. Baldwin, Cave and Lodge, above n 5, 409

12. Ibid, 144

13. Baldwin, Cave and Lodge, above n 5, 40 .

14. Bronwen Morgan and Karen Yeung, An Introduction to Law and Regulation: Text and Materials (Cambridge University Press, 1st ed, 2007) 18.

15. Baldwin, Cave and Lodge, above n 5, 43.

16. Ibid 53

17. Jalilian, Kirkpatrick and Parker, above n 7,89.

18. David Bilchitz, The Moral and Legal Necessity of a Business and Human Rights Treaty (14 May 2016) <https://business-humanrights.org>

19. Ibid.
} 


\subsection{The Role of International Donor Organization}

Many international donor organizations focused on the regulatory matter in developing countries. They are helping government on building their regulatory design and organization and mostly intended to bring an efficient and effective market to provide a stable investment environment. ${ }^{20}$ The existence of international donor organization whether through the conditionality requirements on making the particular structure in the institution or by providing resources to develop the regulatory institution's capacity then brings some pro and cons in the many countries. ${ }^{21}$

Regardless some benefit that might be carried by International donor organization, there were some worries that the international organization would apply a 'one-size fit all' concept which is made based on the best practices that occurred in developed countries and it less likely to be fit with the economic institutional condition in developing countries.

The leverage of international organization towards developing countries also reflects on the international indicator build by an international organization to assess countries particular condition based on its performance. ${ }^{22}$ In regulatory matter, the international organization particularly measure country's performance on effectuating its regulatory instrument to accommodate the investor in doing business in such countries, such as ease of doing business index, Burden of Government Regulation by World Economic Forum, FDI Regulatory Restrictiveness index by Organization for Economic Cooperation and Development (OECD). These ranks were measured by gathering some indicators ${ }^{23}$ based on the developed country point of view.

This condition can be explained by the professionalization theory, where the international organization tries to bring developing countries to the notion of development on exposing some set of standards through knowledge made by the Western country. They were also tried to translate Third World conditions with their own paradigm. This process then followed by institutionalization, where this knowledge was spread to many institutions from an international organization to national and local planning agencies, to the institution outside the government. ${ }^{24}$

\subsection{Regulatory Agency}

Making an effective regulatory policy not only stress on how to design the technical instrument but also required an adequate institution and reliable capacity. Institution building is known as the toughest problem facing by most developing countries. ${ }^{25}$

According to New Oxford Companion, regulatory agency refers to a range of organizations which shape and direct social behavior so as to contribute to the attainment of whatever goals a society wishes to achieve. The regulatory agency is commonly a representative of the state or it can also establish as a part of central government. ${ }^{26}$ In western country, independent agency as representative of the state is more widely used. There is also a notion self-regulation in which agency is an independent institution that operated without government involvement. The level of state involvement may vary from the agency that completely independent to the comprehensive state control or with some mixed of those two types. ${ }^{27}$ In developing countries, institution building perceived as the hardest problems.

\subsection{Regulatory Quality}

The quality of regulation can be assessed by looking at its effectiveness and efficiency arose from the impact of enacted regulation. ${ }^{28}$ In developing countries, the regulation is considered effective if the government's main purpose such as social welfare and poverty reduction achieved by the existence of particular regulation. Meanwhile, efficient regulation accomplished if the government purposes achieved with a minimum cost. ${ }^{29}$ Cost are categorized in two forms

\footnotetext{
20. Colin Kirkpatrick, 'Assessing the Impact of Regulatory Reform in Developing Countries' (2014) 34 Public Administration and Development 162 21. ibid

22. Sally Engel Merry, 'Measuring the World : Indicators, Human Rights, and Global Governance' (2011) 52 Current Anthropology $83,85$.

23. Merry, aboven 21 .

24. Arturo Escobar, Encountering Development: The Making and Unmaking of theThird World (Princeton University Press, 1995) $45-46$.

25. C Kirkpatrick and D Parker, 'Regulatory Impact Assessment and Regulatory Governance in Developing Countries'. 24 Public Administration and Development 333

26. Peter Cane and Joanne Conaghan (eds), The New Oxford Companion to Law (Oxford University Press, 2008).

27. Ibid

28. Jalilian, Kirkpatrick and Parker, above $n 7$

29. Ibid 31 .
} 
such as a direct cost to implement the regulation and the compliance cost which are imposed on the communities either for conforming with or avoiding the regulation..$^{30}$

Some scholars also associated regulatory quality with the state's good governance. ${ }^{31}$ Regulatory system deemed well functioned if it generates the accountability, transparency and consistency. The regulatory agency is required to be accountable for their action on the whole of the regulatory making process and on deciding its decision. They also need to perform a transparent process which involved related stakeholders and implements consistently. ${ }^{32}$

Good regulatory practices also determined by the number of the regulation itself. To reach the desired goal, regulation must be at the minimum necessary. Government can choose not to make some regulation and select several alternatives such as self-regulation, voluntary standard, make socialization strategies and etc. If some condition cannot be overcome by these alternatives, then the only choice is to make a regulation. ${ }^{33}$

\subsection{Deregulation}

Along with its respectable intention as to fulfil citizen's basic needs, regulation might end up with the condition that contrary to its purpose or even could cause an adverse impact on the citizen. To mitigate a broader impact particular mechanism should be done. Deregulation, known as a policy tool to reduce or dismiss government regulation, is one of the best ways to overcome this problem. ${ }^{34}$

Deregulation is a policy tool to overcome this pernicious effect by reducing or diminishing the existence regulation to an appropriate number. It is commonly associated with the market economy condition which aiming to reduce the regulatory burden. ${ }^{35}$

\section{Analysis: Regulation Issues in Developing Hydroelectric Power Plan Indonesia}

To achieve economic growth and sustainable development, providing a good and affordable basic service for its citizen is the main requirement for developing country. The government in developing countries should firstly fulfil its citizen basic needs and it then leads to the pace of market development and output growth. ${ }^{36}$

Currently, Indonesia is still struggling to fulfil its citizen's basic needs such as housing, water and sanitation, electricity, transport, telecommunications, etc. Particularly on electricity, the total ratio electrification in Indonesia in 2014 was approximately 81, $51 \%$. This number means that the other $18,5 \%$ Indonesia's citizen were not enjoying electricity in their daily life. There were also some areas with the greater electrification ratio under $60 \%$ such as East Nusa Tenggara and Papua. ${ }^{37}$

The existence of basic infrastructure might improve the ability of citizens to upgrade their household well-being which in the long run will contribute to economic growth. The availability of electricity should be the crucial point to develop. Electricity is not only a basic right for its citizen but also a prerequisite for the next ladder in economic development. In Global Competitiveness Index 2012-2013, the lack of electricity or inadequate of electrical conditions is one of the main cause of the low rate investment in Indonesia. ${ }^{38}$

There is myriad way on fulfilling the access to electricity, from harness geothermal, solar power, stem power and also from the water power. Of the options, increasing the utilization of hydroelectric power plant is one of the appropriate policies to generate much more electricity.

To meet its citizen electricity needs, the establishment of hydroelectric power plant is crucial as there were a lot of potential site in this country. Currently, hydroelectric power plan gives only $7 \%$ contributions to the national electricity. ${ }^{39}$ President Jokowi on his election program launched a 35 thousand megawatt project power projects to fulfil these electricity

\footnotetext{
30. Baldwin, Cave and Lodge, above n 5, 30 .

31. Parker, D (1999), Regulation of Privatized Public Utilities in the UK: Performance and Governance. International Journal of Public Sector Management, 12 (3), 224.

32. Jalilian, Kirkpatrick and Parker, above $n 7$.

33. Coen JG Holtzappel and Martin Ramstedt, Decentralization and Regional Autonomy in Indonesia: Implementation and Challenges (Institute of Southeast Asian Studies, 2009) 153

34. Marc Allen Eisner, Jeffrey Worsham and Evan J Ringquist, Contemporary Regulatory Policy (Lynne Rienner Publishers, Inc, 2 nd ed, 2006$) 15$.

35. Jalilian, Kirkpatrick and Parker, above n 7,87.

36. Kirkpatrick, Parker and Zhang, above $\mathrm{n} 9,143$

37. National Development Planning Agency, above n 1, 9-10.

38. Klaus Schwab, 'The Global Competitiveness Report 2012-2013' (World Economic Forum, 2012).

39. National Development Planning Agency, above n 1,9-16.
} 
needs ${ }^{40}$ to double the number of hydropower is one of the main projects to achieved 35 thousand megawatts at the end of 2019. ${ }^{41}$

While government determined to achieve this ambitious goal on building dozens of hydroelectric power plant that scattered throughout Indonesia, there were major obstacles that might impede the achievement of this goal. Utilizing water resources is a very complex and required a multi discipline approach and cross sectoral policy. ${ }^{42}$ The main hindrance to achieving this goal came from the existence of regulations related to hydroelectric power plant development, such as over regulation lack of government institution.

\subsection{Over regulation}

In the last 5 decades, Indonesia has approximately forty two thousand regulations which spread in various levels, from national to local regulation, such as act, government regulation, presidential decree, and also local regulation, ${ }^{43}$ not to mention that there is also a technical regulation at the ministerial level ${ }^{44}$ which was not included in the amount.

Every ministry has a discretion and authority in forming the act. Although the establishment of the act must go through the legislation process, the government also has a large influence on determining the content and amount of legislation that will be created within a certain period of time. ${ }^{45}$ On the level of ministerial regulation, the minister can make their own rule in the particular area, with a minimum requirement of coordination with other ministries. There is an emerging trend along the ministers that most problems be addressed easily by making some regulation. ${ }^{46}$

This trend was also happened at the local level. Indonesian government held a regional autonomy after the fall of Soeharto regime on 1998. Local government was granted a broader role on making a practical regulation in a particular matter in accordance with the specific local context. ${ }^{47}$ With this new authority, every local government along with their specific culture condition tends to impulsively make more rules. A trend that occurred at the national level also occurred at the local level.

Unfortunately, instead of solving the problem, this trend on making more regulation gives more burdens to the society and creates a legal certainty among them. ${ }^{48}$ Worse still, this condition would hamper the investors to make some investment in Indonesia and state failed to achieve social welfare.

In order to obtain the license in developing hydroelectric power plant, the investor has to engage with at least 6 ministries at the national level and with the local government. The institutions are the ministry of public works, ${ }^{49}$ the ministry of energy and mineral resources, ${ }^{50}$ the ministry of forestry, ${ }^{51}$ Capital investment coordinating board, ${ }^{52}$ State Electricity Company ${ }^{53}$ and ministry of finance. In each institution, the investors have to do some stages which mostly take a very long time. Until this recent time, the investors of hydroelectric power plant must comply with at least forty four national level regulations and should gain at least fourteen licenses from the various ministries. The figure does not include the license from the local government such as principle permits, location permits. Licenses zoning, building permits and nuisance permit (hinderordonnantie).

The is a problem occurred in West Java, at Cisokan upper hydroelectric power plant, which constrained by the overlap licensed problem from the same ministry, such as principle permits

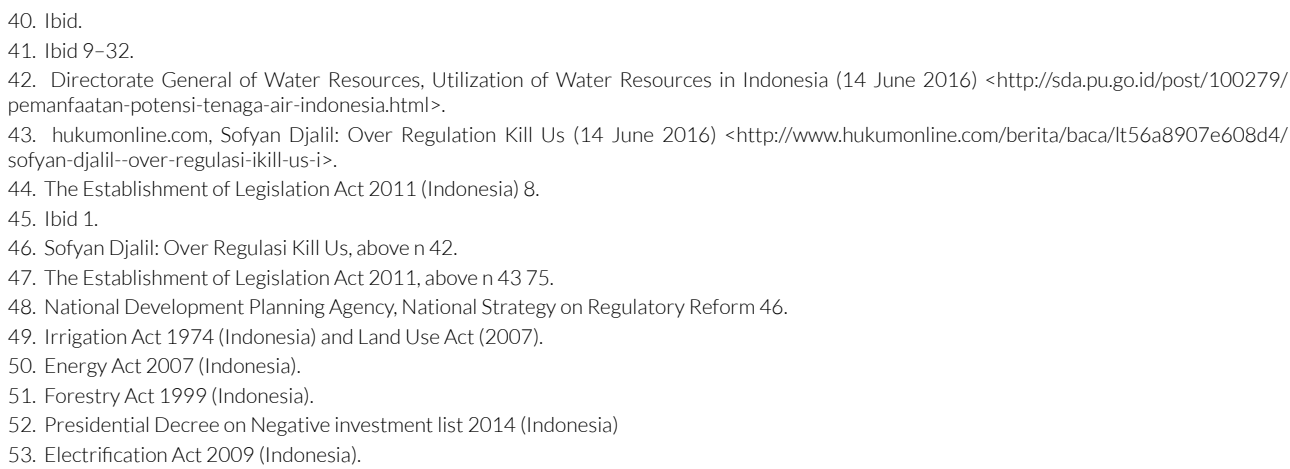


and lease permits from the different directorate general at the Ministry of Forestry. ${ }^{54}$ This condition explains the chaos in the regulatory-making mechanism which lacks of coordination and supervision.

In addition to the excessive number of licensing issues, the regulation problem also occurred on the matter of land acquisition for hydroelectric power plant areas. Overlap regulation governing the land acquisition between the National Land Agency and Ministry of forestry, and also with the local government might obstruct the development of hydroelectric power plant in Indonesia. The 88 megawatt project in Peusangan, Aceh which already obtained the license and started their project, found their difficulties on land acquisition. Hydropower development was already reach $56,7 \%$ and now stagnant because of this matter. ${ }^{55}$

This particular condition of licensing spread over many ministries can also be associated with the allegation of corruption held by each ministry. As Cornelius Tacitus quotes that the more corrupt state the more numerous the laws.

\section{Lack of Government Institution}

Beside of the big number of regulation particularly on licensing and land acquisition, there was also a problem in the lack of government capacity to coordinate particularly in the regulatorymaking mechanism. From the dozen licenses that should be obtained by the investors, it can be analysed that there are three licenses on the same matter that can be simplified. There is license for the use of water resources from Ministry of Public Works ${ }^{56}$ and another two licenses for the utilization of water and water energy in the forest conservation ${ }^{57}$ from the Ministry of Forestry. Instead of being simplified, those three licenses was still scattered in different ministries.

A lot of licenses on national and local level caused the different period of validity. The overlapping on one and another regulation indicates that there was no effective coordination between the ministries and also between the government at national and regional level. ${ }^{58}$

Emersion of this particular problem is allegedly caused by the obscurity institutional system on managing regulation. The fact that many regulations governing the development of hydroelectric power plant comes from the ministerial level means that there is no institution to coordinate whether in the regulatory-making process or when the problems occur between them. Sectoral ego becomes a big issue when it comes to regulatory-making and license authority. ${ }^{59}$ Each ministry has its discretion to make a policy without performing intense coordination with the other related ministries. In fact, the coordination between ministries should have started before they making the regulation but from the first policy formulation. ${ }^{60}$

In regard to regulatory policy, Indonesia does not have an institution which has a full authority to nationally manage the regulation from the national level, including the ministerial decree, to the local level. ${ }^{61}$ The authority on formulation policies and the making of regulation scattered in many ministries. Ministry of Law and Human Rights as one of ministry that has a special structure to coordinate the other ministries on legislation related matter did not have any authority to handle the policies (content of regulation). It only handles some part of the process of regulatory making, namely the harmonization and facilitation in the parliament process.

This lack of government's institution to coordinate the policy making process and the regulatory making process might lead to the overlap implementation. ${ }^{62}$ Even worse, these overlap regulation commonly emerged from the same level government and they tend to persist with the condition with no one would budge. This condition which cannot perform the good regulatory function would lead to the uncertainty to the investors and would harm the society in the long run.

54. Tempo.Co, The Development of Cisokan Upper Hydroelectric Power Plant Considered Illegal (16 June 2016) <https://m.tempo.co/read/ news/2015/12/07/090725550/pembangunan-plta-upper-cisokan-dinilai-ilegal-ini-alasannya>.

55. 88 MW Peusangan Hydroelectric Power Plant Constrained by Land Acquisition (30 June 2016) < http://www.pln.co.id/blog/plta-peusangan88-mw-terkendala-pembebasan-lahan/>.

56. Minister of Public Works and Housing Regulation Number 37/PRT/M/2015 Regarding the Use of Water or Water Resources License'.

57. Government Regulation Number 12 (2014) regarding the type and rate of non-tax revenue in Ministry of Forestry.

58. National Development Planning Agency, above $n 1$.

59. President Urges State Institutions Not Get Caught on Sectoral Ego hukumonline.com (23 June 2016) <http://www.hukumonline.com/berita/ baca/It55cd2c4bb3ab3/presiden-imbau-lembaga-negara-tidak-terjebak-ego-sektoral>

60. National Development Planning Agency, above $n$ 47, 46.

61. Ibid 45 .

62. Overlapping Regulatory Authority Must Be Terminated (30 June 2016) <http://www.hukumonline.com/berita/baca/hol14277/tumpang tindih-kewenangan-izin-investasi-harus-diakhiri>. 
Eventually, instead of gained social welfare to its citizen, this condition will not give a big impact on development hydroelectric power plant. Government's goal of providing electricity for the entire citizen will not be achieved.

In the nineteenth century, UK has this notion of the specialist regulatory institution regarding the public goods matter. In 1884, United States has their own independence regulatory bodies on handling the matter of railroad pricing in the market. This institution then followed by a series regulatory agencies in many areas and mostly in the market condition. ${ }^{63}$ Learn from the experience of developed countries, Indonesia developing a regulatory body which have a full authority might consider as good problem solving overcoming these problems in Indonesia.

\subsection{Regulatory Reform}

\subsubsection{Regulatory Framework As One Of Delivery Mechanism To Fulfil Development Agenda}

One of the five criteria on benchmarking a good regulation is its efficiency, whether on implementing what is the instruction of the legislative or how the regulators interact with the other agencies or departments. ${ }^{64}$ Along with the existence of regulatory problems in regard to developing a hydroelectric power plant in Indonesia, we can see that some institutions were conducting almost the same licensed to the same applicant.

The problem emerged on the basis that licenses are issued by the same level of ministries. These lack of coordination between ministries than pulled back to the process of development planning.

National development planning system act ${ }^{65}$ has mandated that regulatory framework should in line with budgeting framework since the very first of the planning process. Unfortunately, until 2015, development plan stated in the planning document are only approached by one delivery mechanism through the budgeting mechanism. Every planned program was scrutinized by whether or not the plan is appropriate and in line with budget availability.

This particular situation of lack of regulatory approach on planning some development program generates new problems. There are a lot of development program which already had an allocated budget but hindered because of regulatory issues. Consequently, the allocated budget did not use properly, the programs were not properly implemented and eventually development that had been promised by the government cannot be enjoyed by the society.

On the other situation, the lack of regulatory approach on development planning might lead to another adverse condition. Since there was no regulatory framework in the planning document, the ministries planned to make some of regulation that was not in line with national development. They might make a regulation based on the interest of the group which is profitable for the particular individual or institutions (Interest group theory). This trend then might increase the number of regulation and solely offer a few impact on development agenda.

In President Jokowi's regime on the period of 2015-2019, development planning methods has changed with adding another approach on its delivery mechanism such as regulatory and institutional delivery mechanism. ${ }^{66}$ The planned program should not only in line with the budget availability but the government should scrutinize whether or not their program are supported by an appropriate regulation and if there were some problem occurred from the existing regulations they also have to identify existing problem and the relevant stakeholder. If government program needs to establish a new regulation, then it should be stated in the planning document.

Indonesia has National Legislation Program as a regulation planning program that coordinates the ministries on the regulation especially act, which will list as an annual and every five year list. This list then is taken to and to be discussed with the House of Representative. This program was more to administrative approach on how to sort some regulation administratively and discussed a little content of the regulation draft. The new regulatory approach then gave a new mechanism in the national legislation program by not only sort some regulation based on some list of administrative requirements, but it has to be scrutinized through a newly added requirements. If the proposed regulation did not state in the planning document then it did not

\footnotetext{
63. Baldwin, Cave and Lodge, above n 5, 5 .

64. Ibid 31.

65. National Development Planning System Act 20044

66. National Development Planning Agency, above n 1, I, 7-1
} 
have budget allocation whether for the regulation making process or the implementation. This kind of regulation cannot be inserted in to the list of the program.

In the 2010-2014 Medium terms national development plan, there were 33 acts that are planned to be made. Of these numbers, there were only 20 acts that include in the list of national legislation program ${ }^{67}$ as a government initiative that would be brought to the legislative process in the House of Representatives. After imposing a regulatory framework program on the 20152019 , planning document is more inclusive to a regulatory approach which incorporates 84 planned regulations to the national legislation program. The development plan is now supported by the relevant regulations. Overall, a new delivery mechanism on regulatory approach was made to ensure the proposed regulation support the achievement of national priorities.

\subsubsection{National Strategy on Regulatory Reform in Indonesia}

On 2015, Indonesian government launched a National Strategy on Regulatory Reform to overcome the emerging regulation problems caused by a mess of national regulatory system in Indonesia. The purpose of the national strategy is to create a high quality, simple and orderly national regulation system..$^{68}$

This document has four strategies to achieved the expected conditions, such as

a. Regulatory Simplification

This strategy was focusing on the existing regulation that still valid and in force which is overlap in implementation. The purpose of the first strategy is to make a proportional number of regulations. This strategy was made to overcome the problem that emerges because of some regulation that is in conflict, inconsistent, multiple interpretations, not operational. ${ }^{69}$

The process will start with the regulatory stock taking followed by identifying the regulatory problem and related stakeholders. Regulatory Simplification strategy has a particular instrument and will come up with the recommendation whether the particular regulation should be maintained, revised or revoked. ${ }^{70}$

The process of simplification required relevant stakeholders to sit together and discussed the occurred problem and decide whether the provision in each regulation is conflict, inconsistent, multiple interpretations or not operational with the other regulation. It is a heavy part because stakeholders tend to defend their authority.

b. Reconceptualization on the regulatory making process

This strategy held by reviewing and restructuring regulatory-making process. The existing mechanism was implemented based on the Indonesian law on the establishment of legislation act. ${ }^{71}$ The existing process stresses on the regulatory making process but does not put too much consideration on the national policy and the evaluation mechanism. ${ }^{72}$ Assessment and research should be done prior to formulating regulation. This strategy also requires the regulator in the ministries to use a regulatory impact assessment against the proposed regulation. This assessment needed to analyse the cost and benefit which may emerge by enacting particular regulation. ${ }^{73}$

The output of this strategy doesn't have to be a regulation; it might be a non-regulatory policy which achieves the same impact as regulation. If the assessment and research recommend making some regulation, then the regulatory process might begin.

c. Restructuration on the regulatory institution.

Indonesia has no regulatory institution which has a full authority to manage regulations nationally. Policy and regulatory making were scattered in the every ministry, while the ministry of law and human rights did not have any authority to handle the content of the proposed regulation, instead, it only has a few involvement in the administrative process. ${ }^{74}$ This condition would lead to more over-regulated condition with quality

\footnotetext{
67. The Establishment of Legislation Act 2011, above $n 43$.

68. National Development Planning Agency, above n 47, 14

69. Ibid 40

70. Ibid 41

71. The Establishment of Legislation Act 2011, above $n 43$

72. National Development Planning Agency, above n 47, 43 .

73. Baldwin, Cave and Lodge, above n 5, 315

74. National Development Planning Agency, above n 47, 45
} 
decreases.

This strategy promotes the idea that the policy and regulatory making should be consolidated in one institution. This might be a very ambitious idea because the proposed institution should cover a very board scope from the fundamental policies to the something that is very technical and operational.

Unlike the regulatory bodies in the UK or the US, the proposed idea is to establish an institution as a part of central government. It must cover a very board regulation matter nationally. This strategy is considered hard to achieve because it requires a very strong political will from the president and also the political party.

d. Capacity building on policy and regulatory maker

There is a study which stated that $80 \%$ regulatory makers in developing countries did not have an appropriate capacity on regulatory matters. ${ }^{75}$ This strategy was made based on the existing fact that most of the regulatory maker did not make the regulation based on the policies that have been made. So besides improving the capacity of regulatory maker, this strategy also aimed problems only focused on the regulatory making process and abandoned the policy making process. The fact that National Strategy on Regulatory Reform also acknowledges the notion of society participation which inseparable from the four strategies above, to ensure that the regulatory making process involves and got an input from the society. This participation was required at every stage of the process from the assessment, research, up to the stage of discussion in the parliament.

\subsection{Tensions and Challenges in Implementing Regulatory Reform on Developing Hydroelectric Power Indonesia}

\subsubsection{Decentralization}

One of the reasons why decentralization might give a positive impact on promoting on regional and national development is it enforce fiscal federalism. ${ }^{76}$ Local government has their own resources - assets, personnel, and finances- and should perform their own government and required to deliver greater public services. ${ }^{77}$ It comes with an expectation that decentralization would perform better resource allocation and better governance. ${ }^{78}$

The notion of regional autonomy or decentralization in Indonesia were acknowledged since 1945 and stated in the very first Indonesian constitution. ${ }^{79}$ Indonesia was declared as eenheidsstaat (unite state) and consist of areas that prescribed by law. As the same thing happened in Columbia, Local government in Indonesia has long been known but it was overshadowed by the central Government. ${ }^{80}$ After the fall of Soeharto regime in May 1998 which performs a centralistic government and brought an imbalance condition between central and local government, ${ }^{81}$ greater authority for local government emerged in 1999. It was stated in the second amendment of the constitution, which emphasize that Local government was granted the authority to manage and organize their own affairs. ${ }^{82}$

Based on the provisions in the second amendment constitution ${ }^{83}$ and the establishment on legislation act, ${ }^{84}$ local government has an authority for regulatory making in some areas which are not mentioned to be cover by the central government. Although given authority was limited to the certain matters, the local government were facing a new trend through this authority. The tendency to make produce more regulation were unavoidable.

The regulatory problem in local government might come from two levels such as the regulatory-making process and the impact of specific regulatory, particularly to the business climate. ${ }^{85}$ On regulatory-making process, many local governments were making a regulation

\footnotetext{
75. Jacobs, S. (2004). Governance of Asia utilities; new regulators struggle in difficult environments. The governance brief, issue 10 , ADB Governance and Regional Cooperation Division: Bangkok.

76. Luis Eslava, Local Space, Global Life: The Everyday Operation of International Law and Development (Cambridge University Press, 2015$) 152$. 77. Edward Aspinall, Greg Fealy and Institute of Southeast Asian Studies (eds), Local Power and Politics in Indonesia: Decentralization and Democratization (Institute of Southeast Asian Studies, 2003) 259.

78. Holtzappel and Ramstedt, above $\mathrm{n} 32,76$

79. Indonesian Constitution s 7.

80. Eslava, above $\mathrm{n} 74,150$.

81. Basuki Agus Suparno, Reformasi \& Jatuhnya Soeharto (Penerbit Buku Kompas, 2012).

82. Second amendment of Republic of Indonesia Constitution, 18

83. Indonesia Constitution 18

84. The Establishment of Legislation Act 2011, above $n 43$

85. Holtzappel and Ramstedt, above n 32, 150.
} 
without clear objectives and they tend to address most of the problem that occurred by enacting a new regulation. ${ }^{86}$ Their intention was commonly shifted form protecting public interest to increase their own-source revenue. ${ }^{87}$ The approach of the regulatory-making in this matter was mostly use the institutional approach, to increase their own revenue. Therefore, most of the regulation made were in regard to taxes and permits, which often might give rise to government benefit but cost most of the communities. The tendency of making a new regulation with no consideration of non-regulatory alternatives lead to an over-regulate condition, which eventually create legal uncertainty for the investors and communities. ${ }^{88}$

Another problem that emerged from the existence of local regulation is instead of giving a legal uncertainty to the investors and community, local regulation tends to disrupt the investment and economic activities. ${ }^{89}$ Local government tends to enact regulations to impose, as an example retribution or taxes, as much as possible without considering the impact of their policy on the business climate and also to the community. ${ }^{90}$ Some of the local government also build a new taxation instrument and often duplicate the higher-level instrument that stated in the higher regulation and nationally applied. ${ }^{91}$

These local regulation problems also occurred in developing the hydroelectric power plan. The local government required investors to obtain the same permit such as principal permit as requested by central government through its agency. Overlap license requirement between central and local government might confused investor and delayed the hydropower project. There was some hydroelectric project that was canceled by the investors because of the complicated and the lengthy of the licensing process. ${ }^{92}$

\subsubsection{The Use Of International Measurement}

International measurement has been a prominent tool to measure that used in international law and development. Indicator is used to measure productivity and accomplishments on some particular matter. The used of indicators were largely acknowledge by international donor organization and also by the government because development variables and particularly the outcome of regulation implementation are mostly intricate to quantify. ${ }^{93}$

The government might use the international index in regulatory matter because of the difficulties in measuring the quality of regulation they made. However, there is also a reason to remain on the particular list on the international index that ranks many of the states. The existence of the country to be stated as a country with some particular condition might invite more investor to the country in hopes of improving the growth.

National Strategy on Regulatory Reform uses two International indicators to measure its implementation on regulatory reform.

a. The burden of Government Regulation on Global Competitiveness Report by World Economic Forum. ${ }^{94}$

This index was made by World Economic Forum, an international organization which focused on public-private organization. The Forum main purpose was to shape global, regional and industry agendas. There are 1000 members who come from the corporations and big global enterprises.

Particularly in the point of the burden of government regulation, the forum assess on how countries organize their performance on giving the permits, on how to regulate this issue and how the countries make a report. The country was scaled from 1 to 7 , the lower the score the more burdensome the country to the investor.

The report gives the numbers of rank but did not give the detailed on context on history how the numbers emerge. ${ }^{95}$

87. Baldwin, Cave and Lodge, above $n 5$.

88. Holtzappel and Ramstedt, above $n$ 32, 153

89. Ibid 155.

90. Ibid 150.

91. Ibid 166.

92. Foreign Investors Complain about the Length of Bureaucratic Permit (30 June 2016) <http://teropongaceh.com/2016/05/investor-asingkeluhkan-lamanya-birokrasi-pengurusan-izin/>

93. Merry, above n 21

94. World Economic Forum WEF_GlobalCompetitivenessReport_2014-15.pdf (29 June 2016) <http://www3.weforum.org/docs/WEF

GlobalCompetitivenessReport_2014-15.pdf>.

95. Merry, above n 21,84.
} 
b. Regulatory Quality on Worldwide Governance Indicator by World Bank

The regulatory quality indicator gives information about the perceptions on how government provides good policies and regulation to promote private sector development.

This perception index was constructed and aggregated from many data, from the representatives and the non-representative sources such as survey institutions, NGO, international organizations, and private companies. It indicators were also combined with many views from the corporation, citizen, and respondent that surveyed in industrial and developing countries. ${ }^{96}$

Some of the survey that constructs the index are world justice project in measuring rule of law, ${ }^{97}$ index about trade policy and the business regulatory environment by Asian Development Bank,98 index on investment and financial freedom by The heritage foundation ${ }^{99}$ and much more indexes from many sources.

The indexes were used as a comparing tool between developing countries and to evaluate the trend overtime. Regulatory Quality Index was aggregated from many indexes; therefore it did not give sharp information about some specific data and cannot be used by either government or international organization to make a policy or decision regarding some particular matter in the country. ${ }^{100}$

Two indexes that stated in the National Strategy on Regulatory reform were focusing on how government promotes private sector development by providing a good business climate to the investor. In the development of hydroelectric power plant context, the existence of burden of government index and regulatory quality index would push the government to provide an effective and efficient regulation to achieve the target on developing hydropower and at the same time reached a great score on the international scale.

By the existence of these indexes, the government was pushed to organize a good regulatory condition, particularly on the licensing regulation. They aimed to achieve a higher rank in this matter so that it will bring many investors to Indonesia.

In the bigger context, regulatory reform was not only intended to provide an effective and efficient regulation to the private sector. In fact, this national strategy has bigger goals on improving the regulatory condition that eventually promote social welfare for its citizen. ${ }^{101}$ Providing a good regulatory condition to the private sector is one of many ways on achieving this bigger goal. In this larger context, there is some critical point on the use of international measurement especially in the government policy document might distract government focus on achieving fulfilling social welfare to the community.

The use of standardized measurement creates by international organization might also raise a problem because it is made on the basis of the regulatory best practices that occurred in the western country, which mostly ignored developing countries special and specific condition. ${ }^{102}$ The government in developing countries makes some effort to follow this pattern brought by the international organization and find some difficulties whether on achieving some set of standards or even to comply with it.

There is a valuable lesson about the notion of using the international measurement in government's document. In Indonesia medium term national development plan 2010-2014, Corruption Perception Index (CPI) was stated as an instrument and target in measuring the progress on how the government implements the eradication of corruption in Indonesia. It is an index produced by Transparency International (TI), ${ }^{103}$ which in the year of 2011, made changes in its assessment methodology and also the range of the score. It range was changed from 1-10, which has used from the very first index in 1995 until 2011, to 1-100 on the 2012 CPI index until now. This change then made confusion in the government because, in order to increase the CPI score, they already make some specific programs and stated in the planning document for the period of 2010-2014. The government should run the programs although it would not have too

\footnotetext{
96. WGI 2015 (29 June 2016) <http://info.worldbank.org/governance/wgi/index.aspx\#home>.

97. The World Justice Project, Strengthening the Rule of Law for the Development of Communities of Opportunity and Equity (29 June 2016 <http://worldjusticeproject.org/>

98. Asian Development Bank Asian Development Bank (30 June 2016) <http://www.adb.org/>.

99. The Heritage Foundation, the Heritage Foundation (30 June 2016) <http://www.heritage.org/> .

100. Merry, above n 21,85

101. National Development Planning Agency, above $n$ 47, 14

102. Escobar, above $n 23,45-46$

103. Corruption Perception Index - Overview (28 June 2016) <http://www.transparency.org/research/cpi/>.
} 
much effect on the achievement of the CPI score.

The changes in the range of CPI score also disconcerting because Transparency International Indonesia did not give any explanation on how to convert the new score to the old scale; the government finds a difficulty in measuring its achievement on performing corruption eradication in Indonesia.

Another problem that might be emerged by the use of an international indicator is that government focus on implementing development program might be biased. In order to maintain its existence in International Community, government tends put a big effort and put too much focused on increasing their rank in international standard. While the government makes some serious effort to obtain the higher rank on international index they might abandon the rest of the variable that is not used as an indicator on the index. In this particular matter, International measurement is like witchcraft that controls the government in supernatural powers. ${ }^{104}$

In my opinion, it is better for the government to measure their own development based on their national index, which made by specific indicator and variable according to their own specific circumstances. As an example, in regard to prevention and eradication of corruption, Indonesia has built its national index on anti-corruption behaviour index ${ }^{105}$ which is based and in line with national context. It was held by Central bureau of Statistic and held in every province in Indonesia. The methodology was built by many stakeholders including an expert on corruption, anthropology and etc. Unlike the international index, ${ }^{106}$ the national index and score are giving a clear picture of the specific condition in Indonesia. Based on that, the government might easily intervene to the occurred problem that emerged in the community.

\subsection{How Hydroelectric Power Plant Development Benefit From Regulatory Reform}

On developing the hydroelectric power plan, the government already made a plan to make a regulatory instrument accelerate the development of hydroelectric power plant which stated in medium term planning document. This regulation was needed given the fact Indonesia has to achieve 35 thousand megawatts in 2019 and to meet the electricity needs of the rest of the citizen. ${ }^{107}$

Regulatory simplification was urgently needed regarding the fact that there were more than forty national regulations set on this matter. Instead of being effective, over-regulation has become a burden on developing hydropower. The government should be scrupulous on handling the regulatory simplification.

It does not mean that the government would ease and facilitate the investors on doing business in Indonesia, but they have to balance state ability on developing the hydropower plan, their citizen needs on energy, and the need of investment from abroad.

Reconceptualization on regulatory making process and the improvement of policy and regulatory maker certainly will give a good impact in general to the good regulatory condition in Indonesia and particularly to the process of developing hydroelectric power plan in Indonesia.

A regulatory institution, as a part of central government with a comprehensive state control might be the main key to the success of regulatory reform in Indonesia. We can see that the authority on policy and regulatory making is scattered in many institutions. Moreover, there is no mechanism on resolve the issue on the overlap regulation and evaluation of existing regulation. This expected institution is intended to overcome this entire regulation problem, therefore a full support from the country leader is essential. We can see that the problem on overlap regulation commonly came from the government itself. They tend to retain the regulation which gives authority to them made by their institution. If the institution exists, the problem of overlap because of over regulation on developing hydroelectric power plant, including the problem with the local government can be solved.

\section{Conclusion}

In the effort of fulfilling citizens' needs on electricity, a lot of hydroelectric power plant has to be built by the government. The capacity of state budget cannot meet the target on building approximately 10 hydroelectric power plants across Indonesia. ${ }^{108}$ Therefore, investor

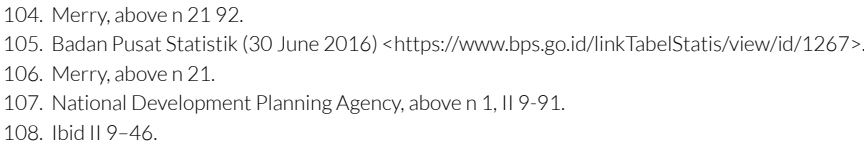


involvement is necessary. Regulation problems that occurred in the process of developing hydroelectric power plant greatly hamper the effort on providing electricity to all Indonesia's citizen. To overcome this issue, national strategy on regulatory reform was made

While reconceptualization on regulatory making process strategy and the capacity building on the policy and regulatory maker strategy might increase the effectivity on the implementation of upcoming regulation, regulatory simplification is the effective strategy that can accurately overcome the existing regulatory problem in developing a hydroelectric power plant in Indonesia. This strategy will give a great impact on achieving government target on fulfilling citizens need on electricity.

Above all of these efforts, building regulatory institutions is the main key to execute regulatory reform in Indonesia. I believe that the existence of regulatory agency with the support of the supreme leader would generate great regulatory conditions in Indonesia and eventually lead to economic growth.

Regarding the challenges in implementing regulatory reform, I believe that decentralization challenges can also be resolved by the existence of regulatory agency with its full authority in regulation matters. If needed, the local regulatory agency can be formed to be more focused on addressing the regulatory problem in the local area. ${ }^{109}$

On the other hand, related with the international indexes used on measuring the Government should more focus to fix the regulation for the further and wider goal, that is to achieve social welfare rather than put too much focused on achieving higher rank in the international index. Focus on building good regulatory condition would automatically improve the country's rank.

Overall, regarding the over regulation condition and lack of government institution I believe that regulatory reform is the most effective way to significantly improve the development of hydroelectric power plan development in Indonesia. 


\section{Bibliography}

Amoore, Louise and Volha Piotukh, Life beyond big data: governing with little analytics (Economy and Society, 2015)

Aspinall, Edward, Greg Fealy and Institute of Southeast Asian Studies (eds), Local Power and Politics in Indonesia: Decentralization and Democratization (Institute of Southeast Asian Studies, 2003)

Baldwin, Robert, Martin Cave and Martin Lodge, Understanding Regulation: Theory, Strategy, and Practice (Oxford University Press, 2nd ed, 2012)

Bilchitz, David, 'The Moral and Legal Necessity of a Business and Human Rights Treaty' $<$ https://business-humanrights.org/sites/default/files/documents/The\%20Moral\%20 and\%20Legal\%20Necessity\%2Ofor\%20a\%20Business\%20and\%20Human\%20Rights\%20 Treaty\%20February\%202015\%20FINAL\%2OFINAL.pdf>

Cane, Peter and Joanne Conaghan (eds), The New Oxford Companion to Law (Oxford University Press, 2008)

Eisner, Marc Allen, Jeffrey Worsham and Evan J Ringquist, Contemporary Regulatory Policy (Lynne Rienner Publishers, Inc, 2nd ed, 2006)

Escobar, Arturo, Encountering Development: The Making and Unmaking of theThird World (Princeton University Press, 1995)

Eslava, Luis, Local Space, Global Life: The Everyday Operation of International Law and Development (Cambridge University Press, 2015)

Gonenc, Rauf, Maria Maher and Giuseppe Nicoletti, The Implementation And The Effects of Regulatory Reform : Past Experience and Current Issues. (OECD, 2000)

Holtzappel, Coen JG and Martin Ramstedt, Decentralization and Regional Autonomy in Indonesia: Implementation and Challenges (Institute of Southeast Asian Studies, 2009)

International Association of Legal Science (ed), International Encyclopedia of Comparative Law (J.C.B. Mohr (Paul Siebeck), 1973)

Iqbal, Farrukh and William E James (eds), Deregulation and Development in Indonesia (Praeger, 2002)

Jalilian, Hossein, Colin Kirkpatrick and David Parker, 'The Impact of Regulation on Economic Growth in Developing Countries: A Cross-Country Analysis' (2007) 35 World Development 87

Kirkpatrick, C and D Parker, 'Regulatory Impact Assessment and Regulatory Governance in Developing Countries.' 24 Public Administration and Development 333

Kirkpatrick, Colin, David Parker and Yin-Fang Zhang, 'Foreign Direct Investment in Infrastructure in Developing Countries: Does Regulation Make a Difference?' (2006) 15 Transnational Corporation 143

Kirkpatrick, Colin, 'Assessing the Impact of Regulatory Reform in Developing Countries' (2014) 34 Publlic Administration and Development 162

Laffont, Jean-Jacques, Regulation and Development (Cambridge University Press, 2005)

Meier, Kenneth, Regulation : Politics, Bureucracy, and Economics (St. Martin's Press, 1985)

Merry, Sally Engel, 'Measuring The World : Indicators, Human Rights, and Global Governance' (2011) 52 Current Anthropology 83

Minogue, M, 'Apples and Oranges-Comparing International Experiences in Regulatory Reform' (2005) Occasional lecture 13 Centre for the Study of Regulated Industries, University of Bath

Morgan, Bronwen and Karen Yeung, An Introduction to Law and Regulation: Text and Materials (Cambridge University Press, 1st ed, 2007)

National Development Planning Agency, Indonesia Medium-Term Development Plan 20152019

National Development Planning Agency, National Strategy on Regulatory Reform

P. Selznick, Focusing Organisational Research on Regulation (University of California Press, 1985)

Schwab, Klaus, 'The Global Competitiveness Report 2012-2013' (World Economic Forum, 2012)

Stiglitz, J, 'Private Uses of Public Interests: Incentives and Institutions' (1998) 12 Journal of Economic Perspectives 3

Suparno, Basuki Agus, Reformasi \& Jatuhnya Soeharto (Penerbit Buku Kompas, 2012) 
Electrification Act 2009 (Indonesia)

Energy Act 2007 (Indonesia)

Forestry Act 1999 (Indonesia)

Indonesian Constitution (Indonesia)

Irigation Act 1974 (Indonesia)

National Development Planning System Act 2004 (Indonesia)

The Establishment of Legislation Act 2011 (Indonesia)

Minister of Public Works and Housing Regulation Number 37/PRT/M/2015 Regarding the Use of Water or Water Resources License

88 MW Peusangan Hydroelectric Power Plant Constrained by Land Acquisition (30 June 2016) <http://www.pln.co.id/blog/plta-peusangan-88-mw-terkendala-pembebasan-lahan/>

Asian Development Bank, Asian Development Bank (30 June 2016) <http://www.adb.org/>

Badan Pusat Statistik (30 June 2016) <https://www.bps.go.id/linkTabelStatis/view/id/1267>

Corruption Perception Index - Overview (28 June 2016) <http://www.transparency.org/ research/cpi/>

Foreign Investors Complain about the Length of Bureaucratic Permit (30 June 2016) <http:// teropongaceh.com/2016/05/investor-asing-keluhkan-lamanya-birokrasi-pengurusanizin/>

Overlapping Regulatory Authority Must Be Terminated 30 June 2016) <http://www. hukumonline.com/berita/baca/hol14277/tumpang-tindih-kewenangan-izin-investasiharus-diakhiri>

hukumonline.com, President Urges State Institutions Not Get Caught on Sectoral Ego (23 June 2016) <http://www.hukumonline.com/berita/baca/lt55cd2c4bb3ab3/presiden-imbaulembaga-negara-tidak-terjebak-ego-sektoral>

hukumonline.com, Sofyan Djalil: Over Regulasi Kill Us (14 June 2016) <http://www. hukumonline.com/berita/baca/It56a8907e608d4/sofyan-djalil--over-regulasi-ikill-us-i>

Tempo.Co, The Development of Cisokan Upper Hydroelectric Power Plant Considered Illegal (16 June 2016)

$<$ https://m.tempo.co/read/news/2015/12/07/090725550/pembangunan-plta-upper-cisokandinilai-ilegal-ini-alasannya>

The Heritage Foundation, The Heritage Foundation (30 June 2016) <http://www.heritage.org/>

The World Justice Project, Strengthening the Rule of Law for the Development of Communities of Opportunity and Equity (29 June 2016) <http://worldjusticeproject.org/>

Utilization of Water Resources in Indonesia (14 June 2016) <http://sda.pu.go.id/post/100279/ pemanfaatan-potensi-tenaga-air-indonesia.html>

World Economic Forum, WEF_GlobalCompetitivenessReport_2014-15.pdf (29 June 2016) <http://www3.weforum.org/docs/WEF_GlobalCompetitivenessReport_2014-15.pdf>

WGI 2015 (29 June 2016) <http://info.worldbank.org/governance/wgi/index.aspx\#home> 